\title{
Experimental Pathology Shared Resource
}

National Cancer Institute

\section{Source}

National Cancer Institute. Experimental Pathology Shared Resource. NCI Thesaurus. Code C39398.

The Experimental Pathology Shared Service provides Cancer Center investigators with access to histotechnology and pathology services including but not limited to routine histologic evaluation, enzyme histochemistry, immunohistochemistry, in situ hybridization, and autoradiog raphy for diag nosis or characterization of tissue sections obtained from animal models. 